\title{
Smothering effect of different crops on weed Malva neglecta Wallr.
}

\author{
Charanjeet Kaur ${ }^{1}$ and Sat Paul Mehra ${ }^{2}$ \\ ${ }^{* 1}$ Regional Research Station, Punjab Agricultural University, Gurdaspur (Punjab), INDIA \\ ${ }^{2}$ Department of Agronomy, Punjab Agricultural University, (Ludhiana), INDIA \\ *Corresponding author. E mail: virgocharan@yahoo.com
}

Received: April 26, 2015; Revised received: February 3, 2016;Accepted: April 3, 2016

\begin{abstract}
Field study was conducted at experimental farm of Punjab Agricultural University ,Ludhiana (India) during rabi seasons of 2004-05 and 2005-06. The experiment was laid out in randomized block design with fourteen treatments having combination of seven different crops viz. bread wheat, durum wheat, six - rowed barley, two-rowed barley, raya, gobhi sarson, linseed and two weed control treatments i.e. hand weeded and unweeded. The study was planned with an objective to find out the most suitable Rabi crop that can suppress the weeds to maximum extent with minimum reduction in yield as there was no herbicide available which can control the weeds in an effective manner. Minimum weed dry matter accumulation was observed in raya $\left(0.97 \mathrm{qha}^{-1}\right.$ in the weeded plot) whereas maximum dry matter accumulation was observed in bread wheat $\left(8.3 q \mathrm{qha}^{-1}\right)$, followed by durum wheat $\left(6.1 \mathrm{qha}^{-1}\right)$, linseed(5.0qha $\left.{ }^{-1}\right)$, barley (6-row) (4.9qha $\left.{ }^{-1}\right)$, barley (2-row) $\left(2.6 \mathrm{qha}^{-1}\right)$ and gobhi sarson (2.4qha $\left.{ }^{-1}\right)$. Raya (Brassica juncea) showed maximum suppressing potential as minimum per cent reduction in crop yield of unweeded over weeded $(7.4 \%)$ and minimum per cent increase in weed dry matter of unweeded over weeded( $44 \%)$ was observed in this crop. Gobhi sarson (Brassica napus) was the next best smothering crop followed by barley (2-row), barley (6-row), linseed, durum wheat and bread wheat, respectively in suppressing the M. neglecta. Two hand weedings treatment proved better in controlling the weeds as compared to unweeded treatment.
\end{abstract}

Keywords: Hand weedings, Malva neglecta, Rabi crops, Smothering effect, Weed control

\section{INTRODUCTION}

Among the various factors responsible for low yield of crops, weed infestation is the major one. It is a major bottleneck to higher wheat productivity, and accounts for more than $48 \%$ loss of potential wheat yield (Khan and Haq, 2002). Weeds are omnipresent pests that compete with crops for water, nutrients, space, and light; host pests and diseases; and release allelochemicals into the rhizosphere (Khaliq et al., 2013 a, 2014 $\mathrm{a}, \mathrm{b})$. The magnitude of weed related losses, however, depends on the type and density of a particular weed species, its time of emergence, and the duration of interference (Estorninos et al., 2005; Hussain et al., 2015).Yield losses are most severe when sources are limited and weeds and crops emerge simultaneously (Zimdahl, 2007; Hussain et al.,2015).Weeds cause maximum damage during the early stages of crop growth. Among the dicot weeds affecting rabi crops, Malva neglecta Wallr. is a new emerging problematic weed, commonly known as common mallow/ button weed/cheese plant/cheese weed and belongs to mallow family (Malvaceae). It is a broadleaf winter annual weed. It propagates through seed. It was introduced from Europe and found throughout in the United States in waste areas, gardens and cultivated land. During 1997 and 1998, it was intercepted and identified in wheat grain consignments imported through 10 major ports of India (Singh, 2001).

Steffey (1980) reported mallow as one of the worst weeds of gardens in the United States and recently, it has become troublesome in field crops causing yield losses of upto 30 per cent in wheat and upto 90 per cent in flax (Makowski and Mortensen 1989). From the Alberta Agriculture weed alert reporting system, M. neglecta was identified as the 49th most abundant weed in major field crops with a maximum density of 6.8 plants $\mathrm{m}^{-2}$ (Dexter et al 1981). Several selective herbicides like metribuzin, linuron, cyanazine, clopyralid ,picloram, chlorsulfuron and metsulfuron methyl have been tried, but none have provided a consistently high degree of control at the rates tested (Donaghy and Sturko 1983a, b; Maurice and Cole 1986). Therefore, the present investigation was carried out to find out the most suitable rabi crop that can suppress the weed Malva neglecta to maximum extent without having much reduction in crop yield.

\section{MATERIALS AND METHODS}

The field experiment was conducted at Students' Farm, Department of Agronomy, Punjab Agricultural University, Ludhiana during the rabi seasons of 2004-05(I year) and 2005-06( II year) in a randomized block design with three replications The soil of the experi- 
mental field was sandy loam in texture, neutral in soil reaction ,low in organic carbon $(0.39 \%)$ and having medium fertility with respect to $\mathrm{N}, \mathrm{P}$ and $\mathrm{K}$ status. The available $\mathrm{N}$ was determined by Modified alkaline potassium permanganate method

( Subbiah and Asija, 1956), available P (0.5 N sodium bicarbonate extractable $\mathrm{P}$ method by Olsen et al, 1954), available K(Lang's Flame photometer by (Jackson, 1967) The experiment consisted of seven different rabi crops like bread wheat ( variety PBW343), durum wheat ( PDW275), six-rowed barley (PL-426), two-rowed barley (DWR 28), Raya (RLM619), Gobhi sarson (GSL-1) and linseed (LC2023), each with two weed management practices i.e. weeded(W) and unweeded (UW).

\section{RESULTS AND DISCUSSION}

Weed population: Weed population was more in second year as compared to first year (Table 1).On average basis, at 60 days after sowing, maximum weed population was observed in bread wheat, followed by durum wheat, linseed, six-rowed barley and two-rowed barley under two hand weedings and unweeded control. Minimum weed population was found in brassica family crops i.e. raya and gobhi sarson. The results are in accordance with Grodzinsky (1992) who observed that brassica family crops in rotations reduced the weed populations up to 40 percent. Similar results were reported by Buhler et al, (1999) that brassica, Sava medic and berseem clover generally reduced lambs quarter weed population more than 80 percent.

Weed plant height: Weed plants growing in oilseed crops ecosystem were shortest in height in comparison to wheat, linseed and barley ecosystems because oilseed crops showed more vigorous growth than other crops (Table $2 \& 5$ ). The findings of the study are supported by Al-Khatib and Boydston (1999) who reported that brassica spp. (B.hirta, B.juncea, B. nigra and B.napus) suppressed weeds through early vigorous growth and smothered weeds before they establish.

Weed dry matter accumulation: Among different Rabi crops, least weed dry matter accumulation was observed in brassica family crops as they suppressed weeds to a greater extent. Similar findings about weed suppression effect were reported by De Haan et al., 1994, who observed that Yellow mustard (Brassica hirta moench) which was sown as a smother crop in corn for 6 to 8 weeks reduced weed biomass by an average of 82 percent. The brassica crop planted in autumn and incorporated before planting of next crop in spring reduced weed biomass by 50-60 percent (Boydston and Hang, 1992).

Crop yield: In all Rabi crops, the yield obtained was more under hand weeding treatments in comparison to unweeded plot which is in uniformity with the results reported by Solie et al, 1991 in wheat. Singh and Saha (2001) also observed minimum weed biomass and maximum grain yield under hand weedings treatment. 
Table 3. Grain/seed yield and straw yield of different rabi crops as influenced by weed control treatments.

\begin{tabular}{|c|c|c|c|c|c|c|c|}
\hline \multirow[t]{2}{*}{ Treatment } & & \multicolumn{3}{|c|}{ Grain yield $\left(\mathrm{q} \mathrm{ha}^{-1}\right)$} & \multicolumn{3}{|c|}{ Straw yield $\left(q h^{-1}\right)$} \\
\hline & & I year & IIyear & Mean & I year & IIyear & Mean \\
\hline \multirow[t]{2}{*}{ Bread wheat } & $\mathrm{W}$ & 45.3 & 43.1 & 44.2 & 62.3 & 58.4 & 60.3 \\
\hline & UW & 40.0 & 37.8 & 38.9 & 54.0 & 50.8 & 52.4 \\
\hline \multirow[t]{2}{*}{ Durum wheat } & $\mathrm{W}$ & 40.7 & 38.5 & 39.6 & 61.6 & 58.2 & 59.9 \\
\hline & UW & 35.6 & 34.6 & 35.1 & 53.1 & 52.0 & 52.5 \\
\hline \multirow[t]{2}{*}{ Barley (6-row) } & W & 30.0 & 32.3 & 31.1 & 57.9 & 60.5 & 59.2 \\
\hline & UW & 25.0 & 31.1 & 28.0 & 51.4 & 57.7 & 54.5 \\
\hline \multirow[t]{2}{*}{ Barley (2-row) } & W & 35.1 & 38.5 & 36.8 & 65.8 & 68.4 & 67.1 \\
\hline & UW & 32.2 & 34.9 & 33.5 & 58.0 & 62.3 & 60.1 \\
\hline \multirow[t]{2}{*}{ Raya } & W & 19.1 & 18.5 & 18.8 & 95.2 & 88.2 & 91.7 \\
\hline & UW & 17.7 & 17.2 & 17.4 & 89.9 & 83.0 & 86.4 \\
\hline \multirow[t]{2}{*}{ Gobhi Sarson } & W & 17.5 & 17.1 & 17.3 & 100.5 & 95.6 & 98.0 \\
\hline & UW & 16.0 & 15.6 & 15.8 & 95.9 & 92.3 & 94.1 \\
\hline \multirow[t]{2}{*}{ Linseed W } & & 14.0 & 13.8 & 13.9 & 49.6 & 48.9 & 49.2 \\
\hline & UW & 12.5 & 12.3 & 12.4 & 47.0 & 46.2 & 46.6 \\
\hline
\end{tabular}

Table 4. Effect of different smothering crops on M.neglecta and crop yield.

\begin{tabular}{|c|c|c|c|c|c|}
\hline Treatment & & $\begin{array}{l}\text { Mean weed dry matter } \\
\text { at harvest( } q / \text { ha) }\end{array}$ & $\begin{array}{l}\text { Mean grain/ } \\
\text { seed yield(q/ha) }\end{array}$ & $\begin{array}{l}\text { \% reduction in crop } \\
\text { yield of UW over W }\end{array}$ & $\begin{array}{l}\text { \% increase in weed dry } \\
\text { matter of } U W \text { over } W\end{array}$ \\
\hline \multirow[t]{2}{*}{ Bread wheat } & $\mathrm{W}$ & 8.3 & 44.2 & - & - \\
\hline & UW & 14.1 & 38.9 & 11.9 & 70 \\
\hline \multirow[t]{2}{*}{ Durum wheat } & $\mathrm{W}$ & 6.1 & 39.6 & - & - \\
\hline & UW & 10.0 & 35.1 & 11.3 & 64 \\
\hline \multirow[t]{2}{*}{$\operatorname{Barley}(6-$ row $)$} & $\mathrm{W}$ & 4.9 & 31.1 & - & - \\
\hline & UW & 7.9 & 28.0 & 9.9 & 61 \\
\hline \multirow[t]{2}{*}{ Barley(2-row) } & $\mathrm{W}$ & 2.6 & 36.8 & - & - \\
\hline & UW & 3.9 & 33.5 & 8.9 & 50 \\
\hline \multirow[t]{2}{*}{ Raya } & $\mathrm{W}$ & 0.97 & 18.8 & - & - \\
\hline & UW & 1.4 & 17.4 & 7.4 & 44 \\
\hline \multirow[t]{2}{*}{ Gobhi sarson } & $\mathrm{W}$ & 2.4 & 17.3 & - & - \\
\hline & UW & 3.5 & 15.8 & 8.6 & 46 \\
\hline \multirow[t]{2}{*}{ Linseed } & $\mathrm{W}$ & 5.0 & 13.9 & - & - \\
\hline & UW & 8.1 & 12.4 & 10.8 & 62 \\
\hline
\end{tabular}

Table 5. Periodic plant height of different rabi crops as influenced by weed control.

\begin{tabular}{llllllll}
\hline Treatments & & \multicolumn{2}{l}{$\begin{array}{l}\text { Plant height(cm) } \\
\text { 90 DAS }\end{array}$} & \multicolumn{3}{c}{ At Harvest } \\
\cline { 2 - 8 } & & I year & II year & Mean & I year & II year & Mean \\
\hline Bread wheat & $\mathrm{W}^{*}$ & 31.1 & 30.5 & 30.8 & 87.2 & 84.9 & 86.0 \\
& UW** & 30.7 & 29.6 & 30.1 & 84.9 & 81.1 & 83.0 \\
Durum wheat & W & 41.7 & 39.8 & 40.7 & 80.8 & 79.5 & 80.1 \\
Barley (6-row) & UW & 39.5 & 38.7 & 39.1 & 79.9 & 78.9 & 79.4 \\
& W & 59.1 & 56.7 & 57.9 & 90.5 & 86.0 & 88.2 \\
Barley (2-row) & UW & 58.4 & 56.1 & 57.2 & 88.4 & 85.2 & 86.8 \\
& W & 64.3 & 62.0 & 63.1 & 100.0 & 97.0 & 98.5 \\
Raya & UW & 62.0 & 60.6 & 61.3 & 99.0 & 97.0 & 98.0 \\
Gobhi Sarson & W & 166.0 & 159.9 & 162.9 & 198.9 & 193.5 & 196.2 \\
& UW & 163.7 & 157.5 & 160.6 & 196.0 & 192.0 & 194.0 \\
Linseed & W & 83.8 & 78.0 & 80.9 & 201.4 & 195.0 & 198.2 \\
& UW & 79.7 & 73.4 & 76.5 & 197.4 & 194.0 & 195.7 \\
\hline
\end{tabular}

* Hand weeding twice, **Unweeded (control)

To find out the smothering potential of different Rabi crops in suppressing the $M$. neglecta, a relation was worked out in yield of different crops and weed dry matter under treatment of two hand weeding and unweeded control. Minimum per cent reduction in yield of unweeded over weeded as well as minimum per cent increase in weed dry matter of unweeded plot over weeded was observed in raya crop as compared to all other crops(Table 4). Among different Rabi crops, raya showed maximum smothering potential followed by gobhi sarson. These findings are in line with the findings of Sarmah et al. (1992), who determined the smothering effect of 11,10 and 8 accessions of Brassica juncea, Brassica napus and Brassica 
carinata, respectively on winter weeds of north east India under field conditions. Grimmer and Mausinas (2004) also observed that brassica spp. can establish quickly and smothers weeds during autumn months. Al -Khatib et al (1997) reported that Brassica crops suppressed the weed growth for several weeks or months. Plant extract combination of brassicasunflower- sorghum presented $80 \%$ weed suppression, which equals to a sole application of synthetic herbicides (Mahmood et al 2015).

\section{Conclusion}

It is concluded that raya showed maximum smothering potential, Gobhi sarson was the next best followed by barley (2-row), barley (6-row), linseed, durum wheat and bread wheat, respectively in suppressing the M. neglecta. Two hand weeding treatment proved better in reducing the weed dry matter accumulation thereby increased the yield in comparison to unweeded control.

\section{REFERENCES}

Mahmood, A., Khaliq, A., Ihsan, M.Z., Naeem, M., Daur, I., Matloob, A. and EL-Nakhlaway, F.S. (2015). Estimation of weed dry biomass and grain yield as a function of growth and yield traits under allelopathic weed management in maize. Planta Daninha, Vicosa - MG 33(1): 23-31

Al-Khatib, K. , Libbye, C. and Boydston, R. (1997). Weed suppression with Brassica green manure crops in green pea. Weed Sci 45(3): 439-445.

Al-Khatib, K. and Boydston, R. (1999). Weed control with Brassica green manure crops. In S. S. Narwal, ed. Allelopathy Update. Volume 2. New Delhi, Calcutta: Oxford Publishing. pp. 255-270.

Subbiah, B.V. and Asija, G.L. (1956). A rapid procedure for the estimation of available

Nitrogen in soils. Curr Sci $25: 259-260$.

Maurice, D.C. and Cole, D.E. (1986). Control of round leaved mallow in barley. Res Rep Expert Comm Weeds (West. Sect.) : 561-562 pp.

Buhler, D.D., Kohler, K.A. and Foster, M.S. (1999). Spring seeded smother plants for weed control in corn and soybeans. Leopold Center Grant Reports. Paper 123

Donaghy, D.I. and Sturko, A.R.W. (1983a). Control of round leaved mallow in wheat. Res Rep Expert Comm Weeds (West. Sect.) 642pp.

Donaghy, D.I. and Sturko, A.R.W. (1983b). Control of round leaved mallow in wheat. Res Rep Expert Comm Weeds (West. Sect.) 642-643pp.

Dexter, G., Nalewaja, J.D., Rasmusson, D.D. and Buchli, J. (1981). Survey of wild oats and other weeds in North Dakota 1978 and 1979, ND. Res Report 79: 80. (Cited from R.M.D Makowski and I.N. Morrison (1989). The biology of Canadian weeds. 91. Malva pusilla $\mathrm{Sm}$. (= M. rotundifolia L.) Can J Plant Sci 69 (3) : 861879.

Solie, J.B., Soloman, S.G., Self, K.P., Peeper, T.F. and Koscelny, J.A. (1991). Reduced row spacing for improved wheat yields in weed free and weed infested fields. Trans ASAE 34: 1654-1660.
Steffey, J. (1980). The mallow family : Malvaceae. Amer Hortic 59: 7-8.

Khaliq, Matloob, A. and Chauhan, B.S. (2014b). Weed management in dry-seeded fine rice under varying row spacing in the rice-wheat system of Punjab. Pak. PlantProd. Sci. 17: 321- 332.

Khaliq, Hussain, S., Matloob, A., Tanveer, A. and Aslam, F. (2014a). Swine cress (Cronopus didymus L. Sm.) residues inhibit rice emergence and early seedling growth. Philipp. Agric. Sci. 96(4) : 419-425.

Khaliq., Hussain, S., Matloob, A., Wahid, A. and Aslam, F. (2013a). Aqeous swine cress (Coronopus didymus) extracts inhibit wheat germination and early seedling growth. Int. J. Agric. Biol, 15(4) : 743-748.

Estorninos, J.L., Gealy, D.R., Gbur, E.E., Talbert, R.E. and Mc-Clleland, M.R. (2005). Rice and red rice interference. II. Rice response to population densities of three red rice (Oryza sativa) ecotypes. Weed Sci. 53(5): 683-689.

Grodzinsky, M. (1992) Allelopathic effects of cruciferous plants in crop rotation. In Allelopathy: Basic and Applied Aspects, eds S.J.H Rizvi and V.Rizvi. New York: Chapman and Hall, pp: 77-85.

M. Khan and N. Haq (2002). Wheat crop yield loss assessment due to weeds. Sarhad J Agri. 18(5): 449 - 453.

Sarmah, M.K., Narwal, S.S. and Yadava, J.S. (1992). Smothering effect of Brassica species on weeds. In Proc. of first national symposium "Allolopathy in agroecosystems: Agriculture and Forestry" held at Haryana Agricultural University,Hisar,India. Feb12-14, pp: 51-55

Jackson, M.L. (1967). Soil Chemical Analysis.Prentice Hall of India Pvt. Ltd., New Delhi.

Grimmer, O.P. and Masiunas, J.B. (2004). Evaluation of winter-killed cover crops preceding snap pea. Hort. Technol.14: 349-355

Boydston, R.A. and Hang, A. (1995). Rapeseed (Brassica napus ) green manure suppresses weeds in potato (Solanum tuberosum). Weed Technol. 9 (4) : 669-675.

Dehaan, R.L., Wyse, D.L., Ehlke, N.J., Maxwell, B.D. and Putnam, D.H. (1994). Simulation of spring seeded smother plants for weed control in corn(Zea mays). Weed Sci. 42: 35-43.

Zimdahl, R.L. (2007). Fundamentals of Weed Science, third ed. Elsevier Inc, U.S.A. 151- 156pp.

Makowski, R.M.D. and Mortensen, K. (1989). Colletotrichum gloeosporioides f. sp. malvae as a Bio-herbicide for round leaved mallow (Malva pusilla) : Conditions for successful control in the field. Proc VII Int Symp Biol Cont Weeds.

Hussain, S., Khaliq, A., Matloob, A., Fahad, S. and Tanveer, A. (2015). Interference and economic threshold level of little seed canary grass in wheat under different sowing times. Environ. Sci.Poll. Res, 22(1) : 441-449.

Singh, S.K. and Saha, G.P. (2001). Productivity and profitability of wheat (Triticum aestivum) as influenced by cultural and chemical weed control. Indian J Agron 46: 475-479

Olsen, S.R., Cole, C.V., Watanabe, F.S. and Dean, L.A. (1954). Estimation of available phosphorus by extraction with sodium bicarbonate. USDA Circ 939: 19 pp Washington DC.

Singh, S. (2001). Interception of weeds in imported wheat grain consignments. Ann Agric Res. 22 (1): 83-87. 